\title{
Keikutsertaan Dalam Kelas Antenatal Dapat Menurunkan Intensitas Nyeri Persalinan Kala I Fase Aktif
}

\author{
Lenny Nainggolan \\ Poltekkes Kemenkes Medan \\ e-mail:lennybidann@gmail.com
}

\begin{abstract}
The antenatal classes are means of learning activity for pregnant woman, together in a group which aimed to increase their knowledge and skills. During the labor process, there are various problems that may occur in the mother, one of which is labor pain. Efforts that can be made to reduce the pain problems are through the implementation of antenatal classes. The purpose of this study was to determine the relationship of antenatal classes and the intensity of labor pain during the active phase of labor. This is an observasional analytic study with cohort design in 33 mothers who attended the antenatal classes. The sampling tehnique that used is consecutive sampling and the data were analyzed by chi-square. As the results of data analysis on the relationship between the antenatal class and the intensity of labor pain during the first stage of active phase, the value of $p=$ 0.000 . The $P$ value $<0.05$. The results of data analysis obtained that there was a relationship between the antenatal class and the intensity of the labor pain during the first stage of the active phase. Midwives are expected to be able to increase the quality of antenatal classes and can attract the interest of the community, especially pregnant woman to actively participate antenatal classes.
\end{abstract}

Keywords: Antenatal classes; Intensity of labor pain

\begin{abstract}
ABSTRAK
Kelas antenatal adalah kegiatan belajar bersama bagi ibu hamil yang dilaksanakan secara tatap muka dalam kelompok yang bertujuan untuk meningkatkan pengetahuan dan keterampilan ibu. Saat proses persalinan terdapat berbagai permasalahan yang mungkin ternjadi pada ibu, salah satunya nyeri persalinan. Upaya yang dapat dilakukan untuk mengurangi masalah nyeri tersebut adalah melalui pelaksanaan kelas antenatal. Tujuan penelitian adalah untuk mengetahui hubungan keikutsertaan ibu dalam kelas antenatal terhadap intensitas nyeri persalinan kala I fase aktif. Penelitian ini merupakan penelitian observasional analitik dengan rancangan kohort pada 33 ibu yang mengikuti kelas antenatal. Teknik pengambilan sampel secara consecutive sampling. Analisa data menggunakan uji chi-square. Hasil analisa data pada hubungan kelas antenatal terhadap intensitas nyeri persalinan kala I fase aktif diperoleh nilai $p=0.000$. Nilai $p<0.05$. Hasil analisa data yang diperoleh terdapat hubungan kelas antenatal terhadap intensitas nyeri persalinan kala I fase aktif. Diharapkan bidan mampu meningkatkan kualitas pelaksanaan kegiatan kelas antenatal dan dapat menarik minat masyarakat khususnya ibu hamil untuk ikut aktif dalam kelas antenatal.
\end{abstract}

Kata Kunci : Kelas Antenatal; Intensitas Nyeri Persalinan

\section{PENDAHULUAN}

\section{Latar Belakang}

Pembangunan kesehatan di Indonesia saat ini masih diprioritaskan pada upaya peningkatan derajat kesehatan ibu dan anak, terutama pada kelompok yang rentan kesehatan yaitu ibu hamil, bersalin dan bayi pada masa perinatal. Upaya yang dapat dilakukakan untuk meningkatkan kesehatan ibu salah satunya adalah pelaksanaan kelas antenatal. Kelas antenatal adalah kegiatan belajar bersama bagi ibu hamil yang dilaksanakan secara tatap muka dalam kelompok dengan tujuan untuk meningkatkan pengetahuan dan keterampilan ibu seputar kehamilan, perawatan kehamilan, persalinan, perawatan nifas, perawatan bayi baru lahir. (1)

Secara alami dalam menjalani proses persalinan setiap ibu akan mengalami risiko permasalahan secara fisik maupun psikologis. Permasalahan yang paling umum dialami oleh ibu bersalin adalah nyeri ketika persalinan. Persalinan merupakan pengalaman fisik yang menimbulkan rasa nyeri. Nyeri tersebut disebabkan oleh adanya kontraksi rahim, sehingga otot-otot rahim mengerut dan menjepit pembuluh darah, dan meregangnya jalan lahir serta jaringan lunak disekitarnya. Rasa takut, cemas dan 
tegang yang dialami ibu sepanjang proses persalinan dapat juga memicu produksi hormon prostaglandin yang dapat menimbulkan stress. Apabila saat bersalin dalam kondisi stress, maka kemampuan tubuh dalam menahan rasa nyeri dapat menurun. ${ }^{(2)}$

Kemampuan bidan saat observasi, pemberian komunikasi, informasi dan edukasi serta bantuannya dapat menjadi penyemangat untuk membantu ibu. Informasi yang akurat dan mudah dipahami yang diberikan kepada ibu tentang kemajuan persalinan dapat juga memberikan semangat. (3) Bidan sangat berperan dalam memperhatikan kondisi psikologis ibu sebagai upaya pengurangan nyeri nonfarmakologis. Pada kegiatan kelas antenatal dilakukan proses edukasi sehingga ibu mendapatkan pengetahuan, keterampilan dan pelaksanaan senam hamil. Kelas antenatal memiliki manfaat dalam kesiapan fisik dan psikologis ibu untuk menghadapi persalinan. (4) Studi yang dilaksanakan oleh Firouzbakht et al., menjelasnakan bahwa terdapat perbedaan yang bermakna antara ibu yang mengikuti senam hamil dengan yang tidak dalam kesiapan psikis dan psikologis dalam menghadapi persalinan. Edukasi prenatal dan dukungan psikologis ibu selama kehamilan dan persalinan sangat berperan dalam penurunan tingkat kecemasan dan intensitas nyeri persalinan. ${ }^{(5)}$

Penelitian tentang kelas antenatal dan hubungannya terhadap intensitas nyeri persalinan kala I fase aktif belum pernah dilaksanakan di Kota Pematangsiantar. Berdasarkan uraian diatas maka penulis tertarik untuk melakukan penelitian tentang keikutsertaan dalam kelas antenatal dapat menurunkan intensitas nyeri persalinan kala 1 fase aktif.

\section{Tujuan Penelitian}

Penelitian yang dilaksanakan bertujuan untuk mengetahui hubungan kelas antenatal terhadap intensitas nyeri persalinan kala 1 fase aktif

\section{Hipotesis}

Terdapat hubungan antara keikutsertaan dalam kelas antenatal dengan intensitas nyeri persalinan kala 1 fase aktif

\section{METODE}

Jenis penelitian adalah observasional analitik dengan menggunakan pendekatan Kohort. Penelitian dilaksanakan di wilayah kerja Puskesmas Martimbang Kota Pematangsiantar pada bulan Juni-Desember 2018. Populasi dalam penelitian adalah seluruh ibu bersalin dan sampel adalah ibu yang pernah mengikuti kelas antenatal. Besar sampel dalam penelitian ini adalah 33 orang ibu primigravida. Teknik pengambilan sampel penelitian adalah consecutive sampling yaitu semua ibu yang datang secara berurutan dan memenuhi kriteria inklusi dan eksklusi dijadikan sebagai sampel sampai jumlah sampel 33.

Intensitas nyeri persalinan diukur pada saat ibu dalam persalinan kala 1 fase aktif, yang digunakan sebagai alat ukur adalah Numerical Rating Scale (NRS). Alat ukur ini menggunakan satu garis horizontal yang terdiratas angka 0-10. Responden diminta untuk mengatakan perasaan nyeri yang dialaminya dengan angka 0-10. Angka 0 mendeskripsikan bahwa ibu tidak mengalami nyeri, angka 1-5 mengalami nyeri sedang dan angka 6-10 mengalami nyeri berat.

Analisis bivariat dilakukan untuk melihat peranan antara variabel independen yaitu kelas antenatal terhadap variabel independen yaitu intensitas nyeri persalinan kala I fase aktif menggunakan uji Chi Square. 


\section{HASIL}

Hasil analisi penelitian yang telah diperoleh disajikan dalam table berikut:

Tabel 1. Karakteristik Resoden Berdasarkan Umur, Pendidikan, Pekerjaan, Pembukaan Serviks

\begin{tabular}{lcc}
\hline \multirow{2}{*}{$\begin{array}{l}\text { Karakteristik } \\
\text { Responden }\end{array}$} & \multicolumn{2}{c}{ Responden } \\
\cline { 2 - 3 } & $\boldsymbol{f}$ & $\%$ \\
\hline Umur & 0 & 0 \\
\hline$<20$ & 31 & 100 \\
\hline $20-35$ & & \\
\hline Pendidikan & 4 & 12,1 \\
\hline SMP & 20 & 60,6 \\
\hline SMA & 9 & 27,3 \\
\hline PT & & \\
\hline Pekerjaan & 28 & 84,8 \\
\hline IRT & 5 & 15,2 \\
\hline Bekerja & & \\
\hline $\begin{array}{l}\text { Pembukaan } \\
\text { Serviks (VT) }\end{array}$ & & 36,4 \\
\hline Akselerasi & 12 & 63,6 \\
\hline $\begin{array}{l}\text { Dilatasi } \\
\text { Maksimal }\end{array}$ & 21 & \\
\hline
\end{tabular}

Karakteristik responden yang mengikuti kelas antenatal $100 \%$ berada pada rentang usia reproduksi sehat yaitu 20-35 tahun. Mayoritas responden berpendidikan tinggi yaitu $87,9 \%$. Sebahagian besar ibu rumah tangga dan pembukaan serviks ketika datang pertama sekali ke BPM wilayah kerja Puskesmas Martimbang adalah fase aktif akselerasi $(63,6 \%)$.

Tabel 2. Hubungan Kelas Antenatal Terhadap Intensitas Nyeri Persalinan Kala I Fase Aktif

\begin{tabular}{|c|c|c|c|c|c|c|c|}
\hline \multirow{3}{*}{$\begin{array}{l}\text { Keikutsertaa } \\
\text { nKelas } \\
\text { Antenatal }\end{array}$} & \multicolumn{2}{|c|}{$\begin{array}{l}\text { Nyeri } \\
\text { Sedang }\end{array}$} & \multicolumn{2}{|c|}{$\begin{array}{l}\text { Nyeri } \\
\text { Berat }\end{array}$} & \multirow[t]{2}{*}{$\begin{array}{l}\text { Tot } \\
\text { al }\end{array}$} & \multirow[t]{2}{*}{$\%$} & \multirow[t]{2}{*}{$p$} \\
\hline & $f$ & $\%$ & $f$ & $\%$ & & & \\
\hline & $\begin{array}{l}2 \\
6\end{array}$ & $\begin{array}{l}78 \\
.8\end{array}$ & 7 & $\begin{array}{l}21 \\
.2\end{array}$ & 33 & $\begin{array}{l}10 \\
0\end{array}$ & $\begin{array}{l}0.0 \\
00\end{array}$ \\
\hline
\end{tabular}

Berdasarkan Tabel 2 dapat dilihat bahwa dari 33 orang responden yang mengalami nyeri berat sebanyak 10 orang $(30.3 \%)$. Hasil uji chi-square diperoleh nilai $p<0.05$ yang berarti ada hubungan kelas antenatal terhadap intensitas nyeri persalinan kala 1 fase aktif.

\section{PEMBAHASAN}

Penelitian tentang keikutsertaan dalam kelas antenatal dapat menurunkan intensitas nyeri persalinan kala 1 fase aktif telah dilaksanakan dan hasil penelitian diolah secara statistik. Seluruh responden adalah primigravida sehingga hasil yang didapatkan lebih bermakna. Studi yang dilaksanakan oleh Bobak memperoleh hasil bahwa ibu yang melahirkan pertama sekali akan merasakan takut dan cemas dalam menghadapi persalinan sedangkan ibu yang sudah berpengalaman akan lebih mampu merespon nyeri dan koping mekanismenya akan baik. ${ }^{(6)}$

Berdasarkan hasil penelitian yang diperoleh mayoritas ibu berumur antara 20-35 tahun yaitu rentang umur reproduksi sehat atau berisiko rendah untuk terjadinya kegawatdaruratan. Ibu yang melahirkan pertama kali pada usia yang terlalu tua atau terlalu muda akan mengalami kecemasan dan nyeri yang lebih hebat. ${ }^{(7,8)}$. Berdasarkan karakteristik pendidikan, sebahagian besar responden berpendidikan tinggi (SMA dan PT), mayoritas ibu rumah tangga dan pembukaan mayoritas pada fase dilatasi maksimal.

Pada penelitian ini hasil uji chi-square diperoleh nilai $p=0.000$ (nilaii $p<0.05$ ), yang artinya ada hubungan pelaksanaan kegiatan kelas antenatal dengan intensitas nyeri persalinan kala 1 fase aktif. Penelitian ini memperoleh hasil yang sejalan dengan penelitian tentang efek edukasi prenatal dalam proses persalinan. Diperoleh hasil bahwa terdapat perbedaan yang signifikan intensitas nyeri persalinan antara ibu yang mengikuti edukasi prenatal dengan ibu yang tidak mengikuti edukasi prenatal. ${ }^{(5)}$

Dalam penelitian ini, meskipun hasil uji statistik signifikan akan tetapi masih ada responden yang mengalami rasa nyeri persalinan yang berat yaitu sebanyak 7 orang. Hal ini dapat terjadi oleh faktor lain baik dari ibu maupun janin. Menurut Tefler definisi nyeri yang sesuai dengan kebidanan yaitu nyeri merupakan fenomena multifaktoral yang subjektif, personal, dan kompleks yang dipengaruhi oleh faktor psikologis, biologis, sosial budaya dan ekonomi. ${ }^{(3)}$ Bidan sebagai profesi yang bermitra dengan wanita, memiliki andil yang cukup kompleks dalam pemberian informasi, edukasi maupun komunikasi yang baik untuk kebutuhan ibu bersalin dan memperhatikan aspek atau faktor yang dapat mempengaruhi persepsi ibu terhadap nyeri yang dialaminya, Bidan juga dapat melakukan asuhan yang optimal untuk menguranginya masalah atau risiko. Upaya pemberian edukasi dan peningkatan keterampilan ibu dapat ditingkatkan didalam pelaksanaan kegiatan kelas antenatal.

Pada pelaksanaan kelas antenatal dilakukan juga kegiatan eksercise atau senam ibu hamil. Penelitian Wagey mendapatkan hasil bahwa kegiatan olahraga dapat memperpendek lamanya kala 1 fase aktif sehingga nyeri persalinan tidak terlalu lama dirasakan oleh ibu dan dengan melaksanakan olahraga pada usia kehamilan trimester akhir dapat terjadi pematangan portio lebih cepat, mengatur aktivitas 
kontraksi uterus yang mempercepat mulainya persalinan. ${ }^{(9)}$

Nyeri dapat menimbulkan suatu perasaan ansietas, sebaliknya ansietas juga sering meningkatkan persepsi nyeri. Rangsangan nyeri mengaktifkan bagian sistem limbic yang dapat mengendalikan emosi seseorang. Dalam persalinan jika ibu mengalami cemas maka dapat menyebabkan terjadinya gangguan otot polos dan pembuluh darah uterus dan terjadilah kekakuan serviks serta hipoksia pada uterus, yang akhirnya menimbulkan impuls nyeri meningkat. Melalui sistem hipotalamus-limbik ke korteks serebri, impuls nyeri dapat menambah perasaan takut dan cemas kemudian kembali ke lingkaran mekanisme semula. $^{(10)}$ Keikutsertaan ibu dalam kelas ibu hamil sangat berperan penting dalam mengendalikan tingkat kecemasan dan intensitas nyeri persalinan.

Perolehan hasil penelitian ini juga sejalan dengan penelitian tentang perbandingan persepsi persalinan bagi ibu primigravida yang mengikuti edukasi prenatal dan yang tidak mengikuti edukasi prenatal. ${ }^{(11)}$ Diperoleh hasil bahwa ibu yang ikut serta dalam edukasi prenatal memiliki persepsi yang baik mengenai persalinan sehingga masalah kecemasan dan nyeri dapat diturunkan. Nyeri persalinan dirasakan oleh hampir semua ibu bersalin akan tetapi sensasi nyeri berbeda-beda pada setiap individu. ${ }^{(12)}$

\section{KESIMPULAN}

Kesimpulan dalam pelaksanaan penelitian ini adalah terdapat hubungan pelaksanaan kegiatan kelas antenatal dengan intensitas nyeri persalinan kala 1 fase aktif. Berdasarkan simpulan tersebut maka perlu untuk bidan agar lebih maksimal dalam pelaksanaan kelas antenatal untuk penanganan rasa nyeri secara non farmakologis bagi klien.

\section{DAFTAR PUSTAKA}

1. Kemenkes RI., Pedoman Pelaksanaan Kelas Ibu Hamil. Jakarta: Kemenkes RI; 2011.

2. Utami, S., 100 Info Penting Persalinan. Jakarta: PT Dian Rakyat; 2008.

3. Cooper, M. A., \& Fraser, D. M., Buku Ajar Bidan Myles. Jakarta: EGC; 2009.

4. Rusmita, E., Pengaruh Senam Hamil Yoga Terhadap Kesiapan Psikis dan Psikologis Ibu dalam Menghadapi Persalinan. Tesis Program Magister Ilmu Keperawatan Universitas Indonesia; 2011.

5. Firouzbakht, M., Nikpour, M., \& Kahfri, S., The

\section{Effect of Prenatal Education on the Process of}

Childbirth. Departmen of Nursing and Midwifery Islamic Azad University; 2014.

6. Bobak, Duncan, M., Jensen, \& Irene., Perawatan Maternitas dan Ginekologi. Bandung: YIAPKP; 2000.

7. Bobak, Lowdermilk, \& Jensen, Buku Ajar Keperawatan Maternitas. Edisi 4. Jakarta: EGC; 2004.

8. Mainunah, Kecemasan Ibu Hamil Menjelang Persalinan Pertama. Jurnal Fakultas Psikologi Universitas Muhammadiyah Malang; 2011.

9. Wagey, F. W., Senam Hamil Meningkatkan Antioksidan Enzimatik, Kekuatan Otot Panggul, Kualitas Jasmani dan Menurunkan Kerusakan Oksidatif Pada Wanita Hamil. Denpasar: Disertasi Program Doktor . Program Pascasarjana Program Studi Ilmu Kedokteran. Universitas Udayana; 2011.

10. Guyton, A. C., \& Hall, J. E., Buku Ajar Fisiologi Kedokteran. Jakarta: EGC; 2007.

11. McDowell, I., Measuring Health: a Guide to Rating Scales and Questionnaires. New York: Oxford University Press; 2006.

12. Sarafino, E. P., Health PsychologyBiopsychosocial Interaction Sixth Edition. USA: Clinical Health Psychology; 2008. 